\title{
Method of growing aseptic culture of zingiber in vitro
}

\author{
N. Bekh, \\ M. Kotsar, \\ M. Roik \\ Institute for Bioenergy Crops and Sugar Beet NAAS of Ukraine
}

The purpose. To develop conditions of stimulation of latent buds on zingiber roots and method of growing aseptic culture in vitro. Methods. Laboratory and biotechnological. Results. Outcomes of probes on stimulation of buds on zingiber roots in conditions of thermal room and thermostat are brought. They compare characteristics of sterilizing solutions "Bilizna" and Sublimate of different concentrations and expositions against infection contamination of zingiber. Conclusions. For stimulation of buds on zingiber roots it is rational to use thermostat with temperature of $28 \pm 2^{\circ} \mathrm{C}$ and moistness of $90 \%$ during $1-2$ months. At getting aseptic culture of buds of zingiber in vitro it is expedient to apply solution of sublimate with weight fraction of $0,1 \%$ and exposition of $45-55$ minutes. That will allow to receive $61,4-81,9 \%$ of viable buds with sterilizing values $50,0-63,9 \%$.

Key words: rhizome, laboratory method, formation of bud, biotechnological method.

In recent decades, Ukraine has seen a growth in popularity of medicinal and spice plants. Widespread became lavender, stevia and various types of mint. Ginger is an important plant used in medicine as an immunostimulator and is widely used in cooking. Ginger has a long history of cultivation and comes from China. Ginger is grown in Asia, West Africa and India. Over the last years, the introduction of plants of this specie was conducted in European countries.

Ginger (pharmaceutical or medicinal, Zingiber officinale Rosco) is a monocots evergreen plant, the family Zingiberaceae [1]. Its root is modified underground sprout (rhizome), which and additional roots and produce sprouts. Rhizome is of primary structure, coating fabric is cork; central axis is cylinder ring of fibrovascular bundles (closed side) parenchyma with numerous fibrovascular bundles (closed side) and cells with essential oil (yellow-green). The stem is erect, rounded, not pubescent [2, 3].

The content of essential oil in dry rhizomes ranges from 1.5 to $3.0 \%$. The main components are $\alpha$ - and $\beta$ zingiberene (zingiber, sesquiterpenes, attributed to organic compounds class of terpenes, up to $70 \%$ ). Also rhizomes contain camphene, eucalyptol, bisabolene, borneol, citral, and linalool. Ginger also contains vitamins $C, B_{1}, B_{2}$, and essential amino acids. Burning taste of ginger is caused by substance gingerol $[4,5]$.

In different countries (Sri Lanka, Egypt, Germany), ginger planting material is obtained mainly by biotechnological methods [6,7]. The method of clonal micropropagation allows to get the released from infection and planting material to grow ginger in Ukraine without purchasing planting material rhizomes. This method is the most reliable way of breeding and conservation of breeding material and is widely used in the reproduction of many agricultural and vegetable crops.

The purpose of the study was to obtain planting material of ginger for growing without purchasing rhizomes that is economically viable and enables introduction of this crop in Ukraine.

\section{Materials and methods}

Ginger rhizomes and buds were used as the starting materials.

The necessary condition for initial explants at rhizomes of ginger is to create a certain culture conditions to produce more quality buds. Therefore we used two methods to stimulate buds formation: conditions of thermal chamber with humidity of $60 \%$, lighting of 3000 Lux. and temperature of $22 \pm 2{ }^{\circ} \mathrm{C}$ (I treatment); conditions of thermostat with humidity of $90 \%$ and temperature of $28 \pm 2{ }^{\circ} \mathrm{C}$ (II treatment). Cultivation was carried out in plastic cuvettes during 1-2 months. 
When the buds were formed as the size of 0.5 to $1.0 \mathrm{~cm}$ they were cut by scalpel with part of the rhizome to $0.5 \mathrm{~mm}$ and washed in soapy solution $(72 \%, 30 \mathrm{~min})$. To get rid of soap, the buds were washed with distilled water 3-4 times. Prepared buds were dipped in a flask with a solution of ethanol $\mathrm{C}_{2} \mathrm{H}_{5} \mathrm{OH}(76 \%$ by weight, for $5 \mathrm{~min}$ ). Under the conditions of sterile chamber, buds were transferred to $100 \mathrm{ml}$ sterile flasks and poured with sterilizing solution:

- I treatment - solution "Bilyzna" ( $35 \%$ by weight) 55 min;

- II treatment - mercury (II) chloride solution ( $0.1 \%$ by weight) $35 \mathrm{~min}$;

- III treatment - mercury (II) chloride solution ( $0.1 \%$ by weight) $45 \mathrm{~min}$;

- IV treatment - mercury (II) chloride solution ( $0.1 \%$ by weight) $55 \mathrm{~min}$;

- $V$ treatment - mercury (II) chloride solution ( $0.2 \%$ by weight) $35 \mathrm{~min}$;

- VI treatment - mercury (II) chloride solution ( $0.2 \%$ by weight) $45 \mathrm{~min}$;

- VII treatment - mercury (II) chloride solution ( $0.2 \%$ by weight) $55 \mathrm{~min}$.

After that the buds were washed by sterile distilled water $\left(\mathrm{dH}_{2} \mathrm{O}\right) 3-4$ times at intervals of 15 to 20 min. Some truncated roots were cut off and aseptic bud of ginger was planted in the Murashige and Skoog medium (MS) without hormones.

To stimulate formation of adventitious shoots viable buds, they were planted on a modified MS medium with the addition of various growth regulators. To analyze the results of research software Statistica 6 was used.

\section{Results}

Studies of stimulating buds formations on ginger rhizomes under the conditions of thermal chamber (I treatment) and conditions of thermostat (II treatment) showed that under high humidity and temperature, buds number increases by 236 compared to the conditions of thermal chamber. The size of the buds also increased, in particular height by $0.4 \mathrm{~cm}$ and a diameter by $0.6 \mathrm{~cm}$ (Table 1 ).

Table 1. Stimulation of buds formation on ginger rhizomes

\begin{tabular}{|c|c|c|c|c|c|c|}
\hline \multirow{2}{*}{ Treatment } & \multirow{2}{*}{$\begin{array}{l}\text { Number of } \\
\text { segments }\end{array}$} & \multirow{2}{*}{$\begin{array}{l}\text { Affected } \\
\%\end{array}$} & \multirow{2}{*}{$\begin{array}{l}\text { Buds } \\
\text { formation } \\
\text { number }\end{array}$} & \multirow{2}{*}{$\begin{array}{l}\text { Bud formation index } \\
\%\end{array}$} & \multicolumn{2}{|c|}{ Size of buds } \\
\hline & & & & & $\begin{array}{l}\text { height } \\
\text { (cm) }\end{array}$ & $\begin{array}{l}\text { diameter } \\
\text { (cm) }\end{array}$ \\
\hline I & 215 & 6.0 & 57 & 0.3 & 1.6 & 0.8 \\
\hline II & 181 & 3.8 & 293 & 1.6 & 2.0 & 1.4 \\
\hline LSD05 & 2.0 & 0.2 & 7.4 & 0.1 & 0.5 & 0.1 \\
\hline
\end{tabular}

When cultured roots in terms of thermal chamber, a slight buds formation $(0.3 \%)$ was observed (Fig. 1) along with the drying and decay of some segments, leading to a loss of $6.0 \%$ starting material. Cultivation of roots under the conditions of thermostat led to a loss of $3.8 \%$ segments.

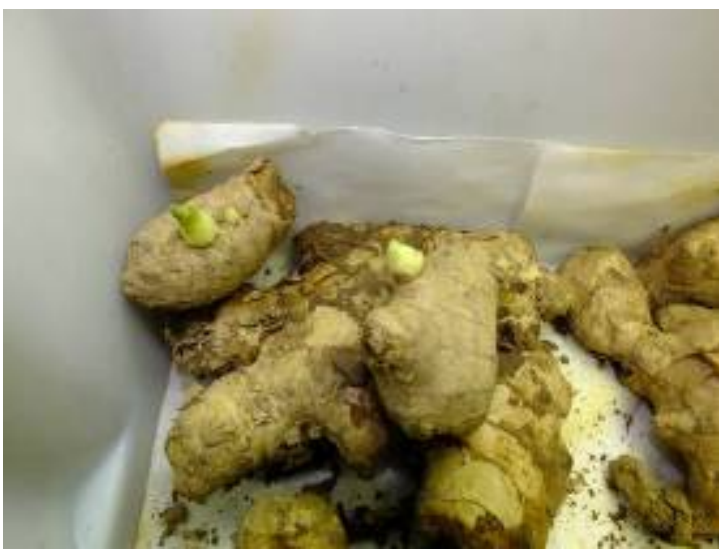

a)

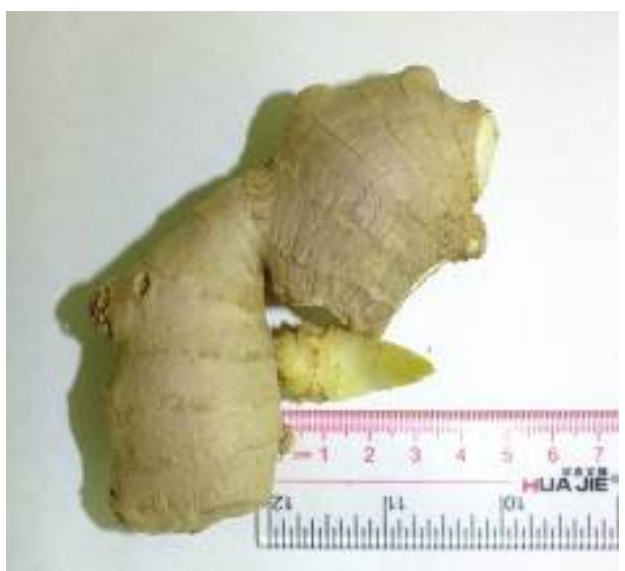

b)

Fig. 1 Stimulation of buds formation on ginger rhizomes:I treatment (a); II treatment (b) 
Studies have shown that the most efficient mean for sterilizing ginger bud is mercury (II) chloride solution ( $0.1 \%$ ) by weight with an exposure of 45 to $55 \mathrm{~min}$, that will allow obtaining 61.4 to $81.9 \%$ of viable buds with sterility 50.0 to $63.9 \%$ (Table 2). When the concentration of mercury (II) chloride to $0.2 \%$ viability of buds was 20.0 to $67.7 \%$ while the number of aseptic buds ranging from 40.0 to $100.0 \%$, but total output aseptic culture buds significantly less than using mercury (II) chloride solution, of $0.1 \%$ by weight. When using the solution of "Bilyzna" with an exposure of 55 min aseptic buds were received.

Table 2. Release of ginger buds from infections

\begin{tabular}{|l|c|c|c|}
\hline \multirow{2}{*}{ Treatment } & $\begin{array}{c}\text { Introduction of } \\
\text { buds in culture in vitro }\end{array}$ & $\begin{array}{c}\text { The viability } \\
\text { buds }\end{array}$ & $\begin{array}{c}\text { Release of buds } \\
\text { from infection }\end{array}$ \\
\cline { 2 - 4 } & number & $\%$ & $\%$ \\
\hline I & 45 & 25.0 & 0.0 \\
\hline II & 40 & 72.5 & 62.5 \\
\hline IV & 43 & 81.9 & 63.9 \\
\hline V & 44 & 61.4 & 50.0 \\
\hline VI & 43 & 67.7 & 67.7 \\
\hline VII & 45 & 40.0 & 40.0 \\
\hline LSD $_{05}$ & 40 & 20.0 & 100.0 \\
\hline
\end{tabular}

After a month of cultivation, $54.9 \%$ of imposed buds formed shoots and roots. Height of the shoots averaged at $2.2 \mathrm{~cm}$, and the number of lateral roots was 4.5 per bud, length $1.9 \mathrm{~cm}$ (Fig. 2). In some buds, only the formation of lateral roots was observed in the amount of 0.6 per bud.

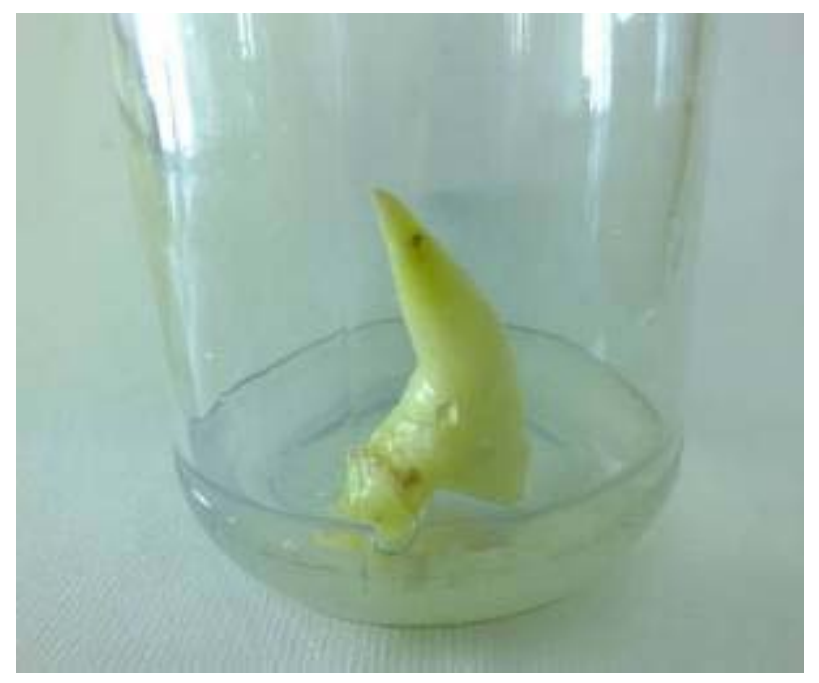

a)

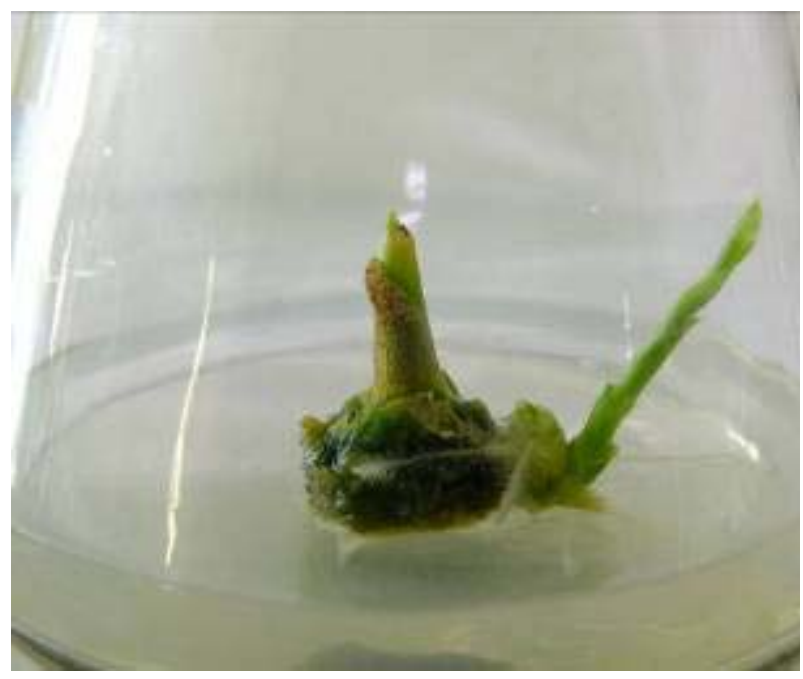

b)

Fig. 2 Release of buds from infection (a); organogenesis (b) in ginger

\section{Conclusions}

To stimulate buds formation on ginger rhizomes it is advisable to use a thermostat at a temperature of $28 \pm 2{ }^{\circ} \mathrm{C}$ and humidity of $90.0 \%$ during $1-2$ months. When receiving aseptic culture of buds of ginger in vitro, mercury (II) chloride solution should be used ( $0.1 \%$ by weight) with an exposure of 45 to 55 min that will allow obtaining 61.4 to $81.9 \%$ viable buds with sterility of 50.0 to $63.9 \%$. 


\section{Bibliography}

1. Abbasa M.S. In vitro propagation of ginger (Zingiber officinale Rosco)/M.S. Abbasa, H.S. Tahab, U.I. Alyb et al.//J. of Genetic Engineering and Biotechnology. — V. 9, Iss. 2. - 2011. - P. $165-172$.

2. Имбиры/Большая советская энциклопедия: [в 30 т.]/гл. ред. А.М. Прохоров. - 3-е изд. - М.: Советская энциклопедия, 1969 - 1978. - С. 142 - 143.

3. Zheng $Y$. Increasing in vitro micro rhizome production of ginger (Zingiber officinale Roscoe)/Y. Zheng, Y. Liu, M. Ma et al.//Physiologiae Plantarum. — 2008. - V. 30. - P. $129-519$.

4. An K. Comparison of different drying methods on Chinese ginger (Zingiber officinale Roscoe)/ K. An, D. Zhao, Z. Wang et al.//Changes in volatiles, chemical profile, antioxidant properties, and microstructure. Food Chem. - 2016. - V. 197 (Part B). - P. 1292 - 1300.

5. McGee H. On Food and Cooking: The Science and Lore of the Kitchen (2nd ed.). - New York: Scribner, 2004. - P. $425-426$.

6. Sathyagowri S. In vitro plant regeneration of ginger (Zingiber officinale Rosc.) with emphasis on initial culture establishment/S. Sathyagowri, H. Thayamini Seran//International Journal of Medicinal and Aromatic Plants. - Iss. 3. - 2011. - V. 1. - P. $195-202$.

7. Islam M.A. Efficient procedure for in vitro microrhizome induction in curcuma longa L.(Zingiberaceae) - a medicinal plant of tropical Asia / M.A. Islam, K. Kloppstech and H.J. Jacobsen//Plant Tissue Cult. 2004. - V. 14(2). - P. $123-134$. 